\title{
The Consumer IN CROSS-Border PASSING OFF CASES
}

\author{
Graeme W Austin*
}

This article considers Starbucks (HK) Ltd v British Sky Broadcasting Group [2015] UKSC 31 in which the Supreme Court of the United Kingdom held that, for the purposes of the passing off tort, goodwill is strictly territorial. It compares this approach with that of New Zealand cases which have adopted a more flexible approach to the protection of goodwill in the cross-border context. The article suggests that, in some cases, the New Zealand approach will be better adapted to consumer experience in the modern international marketplace.

\section{INTRODUCTION}

While the consumer is central to the tort of passing off, we cannot peer into the minds of all the actual consumers who have been or might be misled by a defendant's conduct. ${ }^{1}$ Instead, our understanding of the consumer is shaped by legal doctrines and forensic imperatives. For example, to succeed in a passing off case, the plaintiff must show that there is confusion among a "substantial number" of the public. ${ }^{2}$ Decisions therefore need to be made about the number of consumers that

* Chair in Private Law, Victoria University of Wellington; Professor of Law, Melbourne University. The author is grateful for the extensive comments on and critique of an earlier draft of this article by the expert participants in the New Zealand Private Law Roundtable, especially from Bill Atkin, Nicole Moreham and Andrew Robertson, and for the excellent research assistance provided by Scott Fletcher, LLB(Hons) student, Victoria University of Wellington. This article also draws from material presented by the author at the Trademark Scholars' Roundtable at Oxford University in June 2015.

1 In essence, the tort of passing off is directed at firms' wrongful representations that their goods are the goods of somebody else: Frank Reddaway Ltd v Banham [1986] AC 199 (HL) at 204. Passing off commonly occurs when consumers are, or are likely to be, misled into purchasing the wrong thing: AG Spalding \& Bros v AW Gamage Ltd [1914-1915] All ER 147 (HL) [AG Spalding] at 149 and Erven Warnick v Townend [1979] AC 731 [Erven Warnick] at 739-740. Liability for passing off can also occur when the source identifying function of a firm's get-up or other indicia of origin are diluted in consumers' minds: Taylor Bros Ltd v Taylors Group Ltd [1988] 2 NZLR 1 (CA) at 37: "in some cases it is legitimate to infer damage from a tendency to impair distinctiveness".

2 Reckitt \& Colman Products Ltd v Borden Inc [1990] RPC 341 (HL) at 407 per Lord Oliver; Neutrogena Corporation $v$ Golden Ltd [1996] RPC 473 (EWCA). 
will satisfy this standard, and the kind of evidence that will be admitted. ${ }^{3}$ The picture of the consumer is especially faintly drawn in the context of interim relief - where, often for good reason, little evidence might be available. ${ }^{4}$ Where there is direct evidence that consumers have been confused, courts have become increasingly concerned about its scalability. ${ }^{5}$ Even the phrase "calculated to deceive", used by Lord Parker in the first clear statement of the elements of the tort, ${ }^{6}$ invites a degree of speculation as to how consumers will actually respond to the defendant's actions. $^{7}$

In passing off doctrine, the "consumer" is thus an abstraction. ${ }^{8}$ The picture of the consumer emerges from a kind of inchoate empiricism; its contours are shaped partly by facts, partly by hunches, partly by judicial experience and partly by doctrinal parameters. Analysis of passing off jurisprudence might therefore usefully include consideration of how passing off doctrine understands or constructs the notion of the consumer. This area of inquiry has become particularly

3 On the admissibility of survey evidence in trademark cases see Interflora Inc v Marks \& Spencer plc [2012] EWCA Civ 1501, [2013] 2 All ER 663 [Interflora]; and Imperial Group plc v Philip Morris Ltd [1984] RPC 293 (EWCA).

4 See Klissers Farmhouse Bakeries Ltd v Harvest Bakeries Ltd [1985] 2 NZLR 129 (CA), setting out requirements for interim injunction.

5 See Premier Luggage and Bags v Premier Co [2002] EWCA Civ 387, [2003] FSR 5 (EWCA), observing that the trial judge accorded too much weight to a single instance of confusion; and Arnotts Ltd $v$ Trade Practices Commission [1990] FCA 473, 97 ALR 555, questioning the utility of survey evidence based on population sampling.

6 AG Spalding, above $\mathrm{n} \mathrm{1,} \mathrm{at} \mathrm{149.} \mathrm{An} \mathrm{earlier} \mathrm{classic} \mathrm{statement} \mathrm{of} \mathrm{the} \mathrm{requirements} \mathrm{is} \mathrm{in} \mathrm{Leather} \mathrm{Cloth}$ Company v American Leather Cloth Company (Ltd) (1865) 11 HL Cas 523 at 538: "The fundamental rule is, that one man has no right to put off his goods for sale as the goods of a rival trader, and he cannot therefore (in the language of Lord Langdale in the case of Perry $v$ Truefitt (6 Beav 66), 'be allowed to use names, marks, letters or other indicia, by which he may induce purchasers to believe that the goods which he is selling are the manufacture of another person."'

7 Christopher Wadlow The Law of Passing Off: Unfair Competition by Misrepresentation (3rd ed, Sweet \& Maxwell, London, 2004) at 8. For instance, in the pharmaceutical labelling context, the public interest in safety might be relevant to a court's analysis of the likelihood that consumers will be deceived or confused by the defendant's representations: see Win-Medicare Pvt Ltd $v$ Galpha Laboratories Ltd High Court New Delhi, 4 January 2016, IA Nos 22711/2014 \& 26365/2014 in CS(OS) No 3507/2014.

8 The construction of the consumer in this sense has become an important theme in United States trademark scholarship: see for example Devan Desai "From Trademarks to Brands" (2012) 64 Fla L Rev 981; Laura Heymann "The Birth of The Authornym: Authorship, Pseudonymity, and Trademark Law" (2005) 80 Notre Dame L Rev 1377; Laura Heymann "The Reasonable Person in Trademark Law" (2008) 52 St Louis University Law Journal 781; and Graeme W Austin "Trademarks and the Burdened Imagination" (2004) 69 Brook L Rev 827. In United States' federal trademark law, there is almost a complete alignment between analysis of the likelihood of confusion in the contexts of passing off and infringement of registered trademarks. 
salient in the light of the trend in cognate jurisdictions to limit the role of empirical evidence about consumer confusion in litigated cases. ${ }^{9}$

Taking these ideas as its springboard, this article focuses on the 2015 decision in Starbucks (HK) Ltd v British Sky Broadcasting Group. ${ }^{10}$ There, the Supreme Court of the United Kingdom held that a Hong Kong firm could not enjoin the actions of another firm in the United Kingdom based merely on the Hong Kong firm's reputation within the United Kingdom. The trial judge had found that there were United Kingdom residents who knew about the claimants' television programmes through exposure to YouTube videos and on demand in-flight entertainment systems. ${ }^{11}$ The Supreme Court held, however, that reputation within the United Kingdom was insufficient: only United Kingdom customers would suffice for the purposes of passing off. Writing for a unanimous Court, Lord Neuberger, President, reasoned that the claimants therefore lacked a protectable property interest.

In this aspect, the "hard line" approach, as Lord Neuberger characterised it, differs from that adopted by courts in a number of other common law jurisdictions. New Zealand and Australian courts have adopted a less rigid approach. ${ }^{12}$ In Conagra Inc v McCain Foods (Aust) Pty Ltd,

9 In the trademark infringement context, for example, the Court of Appeal of England and Wales has recently held that survey evidence is "generally of little or no value": Interflora, above n 3, at [135]-[141]. See also Kate Swain and others "Surveying Trade Mark Surveys" Managing Intellectual Property (online ed, February 2013) at 49. New Zealand courts have thus far adopted a more pragmatic approach to the admissibility of survey evidence, taking the view that the weight to be accorded to such evidence is a matter for the court: Levi Strauss \& Co v Kimbyr Investments Ltd [1994] 1 NZLR 332 (HC) [Levi Strauss] at 364. Occasionally, surveys might be criticised for asking the wrong kinds of questions: see for example Mainland Products Ltd v Bonlac Foods (NZ) Ltd [1998] 3 NZLR 341 at 350 (CA), criticising a telephone survey in the context of a case turning on a visual comparison). In some instances, a survey might be admitted, but accorded relatively little weight: see Patience \& Nicholson (NZ) Ltd v Cyclone Hardware Pty Ltd [2001] 3 NZLR 490 (HC) [Patience \& Nicholson] at [90]-[91]. New Zealand courts have not yet engaged with the approach of the English courts to survey evidence. In Intercity Group (NZ) Ltd $v$ Nakedbus NZ Ltd [2014] NZHC 124, [2014] 3 NZLR 177 at [123], Asher J discussed a later stage of the Interflora litigation in-depth, but did not discuss the Court of Appeal's reservations as to admissibility. This was, however, in a context in which the survey evidence was regarded as highly probative. Recently, in Commerce Commission v New Zealand Nutritionals (2004) Ltd [2016] NZHC 832, in a claim under the Fair Trading Act 1986 (FTA), the absence of survey evidence was held not to be fatal to the Commerce Commission's claim. In Tasman Insulation New Zealand Ltd v Knauf Insulation Ltd [2015] NZCA 602, [2016] 3 NZLR 145 at [254], in the context of a claim under the FTA, the Court of Appeal also resisted attacks on survey evidence, and considered it to reinforce the Court's own impression as to the meaning conveyed by the mark at issue.

10 Starbucks (HK) Ltd v British Sky Broadcasting Group [2015] UKSC 31, [2015] All ER 469 [Starbucks (SC)].

11 At [5].

12 As have several other common law jurisdictions: Caterham Car Sales \& Coachworks Ltd v Birkin Cars (Pty) Ltd [1998] 3 All SA 175 (Supreme Court of South Africa); Staywell Hospitality Group Pty Ltd v Starwood Hotels \& Resorts Worldwide Inc [2013] SGCA 65, [2014] 1 SLR 911 (Singapore Court of 
Lockhart and French JJ held that it sufficed for the plaintiff to establish a reputation in the jurisdiction. ${ }^{13}$ Neither a physical business presence in the jurisdiction nor a place of business was required. On this analysis, those who might be harmed by the defendant's actions need not be "customers". Similarly, in the New Zealand High Court, Eichelbaum J held in Midas International Corporation v Midas Autocare Ltd that it was sufficient in an interlocutory injunction application for the plaintiff to rely on evidence that it had a considerable reputation in its field, both in its home country (the United States) and Australia. ${ }^{14}$ His Honour observed that though the plaintiff had not traded in New Zealand its reputation would be known to New Zealanders who had seen advertising in material circulating in New Zealand and to those who had become of aware of the plaintiff's operation by reason of travel overseas. ${ }^{15}$ Were it necessary to establish that the plaintiff had business activity within New Zealand, his Honour considered that its negotiations for the establishment of a franchise would have sufficed. ${ }^{16}$

In Dominion Rent A Car Ltd v Budget Rent A Car Systems (1970) Ltd the New Zealand Court of Appeal adopted a more radical approach, holding that a firm's goodwill could transcend international boundaries and that, for some trans-Tasman businesses, it would be artificial, for the purposes of passing off, to divide a firm's goodwill into separate Australian and New Zealand bundles of rights. ${ }^{17}$ In a 2013 New Zealand High Court decision, Toogood J referred to Cooke P's analysis in Dominion Rent A Car and opined: "In 2013, it can hardly be doubted that New Zealand and Australia may, for the purposes of enforcing intellectual property rights, be regarded as one

Appeal) [Staywell]; N R Dongre v Whirlpool Corporation [1996] SCR 5 Supp 569 (Supreme Court of India); and Mac Personal Care Pvt Ltd v Laverna Gmbh and Co 28 January 2016 FAO (OS) 194/2015 (High Court of Delhi)

13 ConAgra Inc v McCain Foods (Aust) Pty Ltd (1992) 33 FCR 302 (FCAFC) [Conagra] at 341-342. In the same case, Gummow $\mathbf{J}$ reasoned that it sufficed for the plaintiff to establish a reputation with a substantial number of persons who would be potential customers if the plaintiff established a business within the jurisdiction; ConAgra at 353. See also Fletcher Challenge Ltd v Fletcher Challenge Pty Ltd and Ors [1981] 1 NSWLR 196 (NSWSC).

14 Midas International Corporation v Midas Autocare Ltd (1987) 2 TCLR 491 (HC) [Midas] at 498.

15 At 498

16 At 498. See also Gallaher Ltd v International Brands Ltd (1977) 1 NZIPR 43 (SC).

17 Dominion Rent A Car Ltd v Budget Rent A Car Systems (1970) Ltd [1987] 2 NZLR 395 (CA) [Dominion Rent A Car] at 406. See also Crusader Oil NL v Crusader Minerals NZ Ltd (1984) 3 IPR 171 (HC); and Patience \& Nicholson, above $\mathrm{n}$ 9, at [32]: "Undoubtedly the forces of closer economic relations between Australia and New Zealand and of globalisation generally mean that there will be increasing opportunities to see that spilling over of reputation." 
market". ${ }^{18}$ In turn, that analysis was adopted obiter by Woolford $\mathrm{J}$ in 2015 , again in the High Court. ${ }^{19}$

Starbucks raises a number of technical points about the territorial scope of goodwill that may be of considerable importance for firms seeking to roll out their products and services on an international scale. ${ }^{20}$ As will be explained below, the distinction between territorially confined and cross-border conceptions of goodwill also exposes different conceptions of the consumer. The contrast between the New Zealand and United Kingdom case law provides an opportunity to consider which of these approaches better accommodates the consumer worldview in the contemporary markets for goods and services, ${ }^{21}$ especially markets for the kinds of weightless goods that now traverse international borders with relative ease. ${ }^{22}$ It also raises a number of intriguing questions about the relationship between private property, territoriality, and the sovereign power of the nation state. The more prosaic doctrinal question posed by Starbucks is whether the New Zealand approach remains sustainable. This article suggests that the Starbucks analysis is not sufficiently compelling to warrant a departure from the New Zealand position on the protection of goodwill across borders.

\section{THE STARBUCKS DECISION}

The Starbucks claimants ran a Hong Kong-based television business that marketed its services under the mark "NOW". Within Hong Kong, the claimants had acquired a substantial goodwill in

18 Muzz Buzz Franchising Pty Ltd v JB Holdings (2010) Ltd [2013] NZHC 1599 at [74].

19 Dreamtech Designs and Productions Pty Ltd $v$ Clownfish Entertainment Ltd [2015] NZHC 1143 [Dreamtech] at [49].

20 Graeme W Austin "Introduction: the Inevitability of 'Territoriality Challenges' in Trademark Law" in Irene Calboli and Edward Lee (eds) Trademark Protection and Territoriality Challenges in a Global Economy (Edward Elgar, Cheltenham, 2014) at 1-2.

21 As the United Kingdom Supreme Court's analysis suggests, it is possible to identify differences between the Australian and New Zealand approaches. Lord Neuberger's reasoning suggested that Dominion Rent A Car's holding that there be goodwill in New Zealand, even if shared between Australia and New Zealand, did not support the Hong Kong entity's case, whereas that case was supported by the Australian courts' willingness to recognise a local reputation as sufficient for the purposes of passing off: Starbucks (SC), above n 10, at [41]-[42]. See also Stephen Todd "Interference with Intellectual Property" in Stephen Todd (ed) The Law of Torts in New Zealand (7th ed, Thomson Reuters, Wellington, 2016) at 763-764. As the discussion of Midas, above n 14, indicates however, there are New Zealand cases that have adopted a more relaxed approach to the interest protected by passing off, one more in line with the approach in ConAgra. For the purposes of this article, it is assumed that, in practical terms, little may turn on this distinction. What might seem like cross-border goodwill through one lens might seem more like local reputation that is protected by passing off through another.

22 Here, the comments of Eichelbaum J in Midas, above n 14, at 497 seem prescient: "having regard to the diminishing importance of international boundaries in the face of the communication explosion I see attraction in an even less demanding approach to the requirement of proof of goodwill". 
that name. By 2012, the claimants' company was Hong Kong's largest TV operator, with subscribers in nearly half of all Hong Kong households. While consumers outside of Hong Kong could not access the claimants' pay TV channel, the firm had nevertheless established a reputation among some viewers outside of Hong Kong, including in the United Kingdom. It operated its own YouTube channel, and had made some of their Chinese language television programmes available through internationally accessible websites. A number of airlines had made the claimants' "NOW" television programmes available through video-on-demand in-flight services. ${ }^{23}$

The dispute arose when the defendants, which were part of the Sky Broadcasting Group, announced in 2012 that they were planning to launch their own Internet television pay-per-view service in the United Kingdom under the name "NOW TV". The claimants initiated proceedings for passing off and infringement of its Community trade mark (CTM) in the NOW mark. ${ }^{24}$ The trial court dismissed the CTM action, holding the mark to be invalid or, alternatively, not infringed. ${ }^{25}$ Accordingly, the claimants could only be protected by way of its common law rights in its goodwill. The Court held, however, that the claimants' reputation in the United Kingdom was an insufficient foundation for a passing off action. The Court of Appeal dismissed the appeals on both issues. ${ }^{26}$ The Supreme Court granted leave only on the passing off point.

The Starbucks holding rests on two propositions. First, goodwill is territorial, meaning that goodwill exists and is protected on a jurisdiction-by-jurisdiction basis. ${ }^{27}$ Accordingly, a firm doing business in country $\mathrm{X}$ and country $\mathrm{Y}$ has two distinct bundles of property rights, one protected under the law of $\mathrm{X}$ and the other under the law of Y. Secondly, the territorial limitations on goodwill mean that it is only customers within the jurisdiction who count for the purposes of establishing whether goodwill exists. The trial judge had held that the claimants' United Kingdom reputation was more than de minimis. ${ }^{28}$ But because the claimants in Starbucks lacked United Kingdom customers, the English law of passing off could not help.

23 The facts are recounted in detail in the first instance decision Starbucks (HK) Ltd v British Sky Broadcasting Group Plc [2012] EWHC 3073 (Ch) [Starbucks (HC)] at [18]-[49].

24 Regulation 40/1994 on the Community Trade Mark [1994] OJ L11/1. This created trade marks which are governed by a uniform Community law directly applicable in all member states.

25 Starbucks (HC), above n 23, at [15]-[116], and [120]-[121]. As to validity, the Court held that the NOW mark was precluded from registration on the basis that it would be regarded by the average consumer as a description of a characteristic of the television service, namely its immediate availability. As to infringement, the differences between the figurative elements of the claimant's mark and those of the defendant's mark would have dispelled confusion.

26 Starbucks (HK) Ltd v British Sky Broadcasting Group Plc [2013] EWCA Civ 1465, [2014] FSR 20.

27 See Wadlow, above $\mathrm{n} 7$, at $154 \mathrm{ff}$.

28 Starbucks (SC), above n 10, at [10]. 
In support of the first proposition, the Supreme Court adopted the analysis of the Privy Council in the famous 1976 decision in Star Industrial Co Ltd v Yap Kwee Kor, an appeal from the Court of Appeal of Singapore. ${ }^{29}$ In Yap Kwee Kor, Lord Diplock set forth the classic statement on the territoriality of goodwill, reasoning that goodwill "is local in character and divisible: if the business is carried on in several countries a separate goodwill attaches to it in each". ${ }^{30}$ Several years before the dispute arose, the plaintiff (coincidentally, another Hong Kong firm) had abandoned the Singapore market, when Singapore ceased to be a free port. The Privy Council held that the plaintiff could not bring a passing off action to enjoin the defendant's activities in Singapore. For the purposes of passing off, the Hong Kong business was separate from any Singaporean business. Accordingly, any goodwill it might have in Hong Kong was irrelevant to the existence of goodwill within Singapore. The Privy Council held that the Hong Kong business and accompanying goodwill did not provide the basis for a cause of action for passing off within Singapore.

The second proposition can be illustrated by a number of earlier authorities holding that protection under the tort of passing off requires customers within the jurisdiction, not merely reputation. In Alain Bernardin et Compagnie $v$ Pavilion Properties Limited, for example, Pennycuick $\mathbf{J}$ declined to grant an interlocutory injunction to restrain a firm from using the name "Crazy Horse Saloon" on the application of a firm that had established a reputation in Paris under the same name. ${ }^{31}$ Because the plaintiff had not offered any restaurant services in the United Kingdom, it could not rely on the passing off tort. Pennycuick J held "with reluctance" that the plaintiff did not have a prima facie case for an injunction, observing that the defendant was "cashing in" on the plaintiff's reputation and had deliberately copied the plaintiff's trade get-up. ${ }^{32}$ A number of other cases similarly reasoned that the territorial nature of goodwill requires trade within the jurisdiction, not merely reputation. ${ }^{33}$

29 Star Industrial Co Ltd v Yap Kwee Kor [1976] FSR 256 (PC).

30 At 269

31 Alain Bernardin et Compagnie v Pavilion Properties Limited [1967] FSR 341 (Ch).

32 At 350

33 Amway Corporation v Eurway International Ltd [1974] RPC 82 (Ch); and Athlete's Foot Marketing Associates Inc v Cobra Sports Ltd [1980] RPC 343 (Ch). Of course, firms that own registered trademarks might be able to rely on rules that protect famous marks that exist in foreign jurisdictions. In broad outline, such marks are protected when they have a sufficient reputation within the jurisdiction in which protection is sought: Paris Convention for the Protection of Industrial Property (opened for signature September 28 1979, entered into force June 3 1984), art 6bis. Also, under the Paris Convention, art 4, all registered trademarks, even those lacking sufficient fame enjoy a six-month priority in the registration context. However, under the Starbucks (SC) analysis, a firm seeking to rely on passing off alone must show customers within the jurisdiction. Their Lordships also invoked the limited protections afforded to famous marks in international law (in essence, the Paris Convention limits these obligations to marks that have achieve fame) in support of the hard line approach to territoriality: Starbucks (SC), above n 10, at [64]. 
A key aspect of the motivation behind the Supreme Court's approach is made clear by its discussion of barriers to market entry for domestic firms. The Court was especially concerned that: ${ }^{34}$

... a claimant could shut off the use of a mark in this jurisdiction even though it had no customers or

business here, and had not spent any time or money in developing a market here - and did not even

intend to do so.

Clearance costs are higher where indicia of origin can be protected both by the registered trademark system and by passing off. The costs of the former involve a search of the register, which, in jurisdictions that have efficient trademark registration systems, can be relatively low. ${ }^{35}$ Searches for unregistered pre-existing indicia of origin (such as can be protected through passing off) are more costly, and involve scrutinising the branding and marketing strategies adopted by other firms in the same market context, including material that has not been registered. Insisting that foreign firms spend time or money within the jurisdiction before they will protected by passing off can be understood as a filtering device that limits the number of firms whose activities needed to be considered by a new market entrant. Foreign firms with a reputation, but no customer base, need not be considered. ${ }^{36}$ In sum, limiting the factual inquiry in this way makes it cheaper for local firms to get to market.

More generally, the hard line approach should limit the scope of the factual inquiry in any case. It is axiomatic that goodwill must be established as a matter of fact: this is the key difference

34 Starbucks (SC), above n 10, at [63].

35 In some jurisdictions there is also a "Supplemental Register" which, whilst not providing rights in marks, acts as a signal to potential competitors that a firm has some reputation in the relevant mark. See for example Lanham Act 15 USC § 1051-1056.

36 This reasoning implies that requiring customers within the jurisdiction can be explained as a kind of quid pro quo: protectable rights are a reward for investment. In the era of cross-border marketing, however, having a business within the jurisdiction no longer means investment of the bricks and mortar kind. Indeed, at a number of points in the Supreme Court's judgment, and in those of the courts below, it is implied that targeting customers within the jurisdiction might be enough. Frequently invoked as a condition for exercising personal jurisdiction, targeting in the relevant sense can involve a fairly minimal investment, and certainly no physical presence: factors include the currency in which purchases can be made, the relevance of advertising on the website to consumers within the jurisdiction, and so on: Case C-173/11 Football Dataco Ltd v Sportradar GmbH [2012] ECR C-242 at [41]. Accordingly, the kind of investment that might justify recognition of property in goodwill is not necessarily for the general benefit of the population. 
between passing off and an action for infringement of a registered trademark. ${ }^{37}$ According to Lord Fraser's formulation in Erven Warninck BV v J Townend Sons (Hull) Ltd a plaintiff must establish: ${ }^{38}$

(1) that his business consists of, or includes, selling in England a class of goods to which the particular trade name applies; (2) that the class of goods is clearly defined, and that in the minds of the public, or a section of the public, in England, the trade name distinguishes that class from other similar goods; (3) that because of the reputation of the goods, there is goodwill attached to the name; (4) that he, the plaintiff, as a member of the class of those who sell the goods, is the owner of goodwill in England which is of substantial value; (5) that he has suffered, or is really likely to suffer, substantial damage to his property in the goodwill by reason of the defendants selling goods which are falsely described by the trade name to which the goodwill is attached.

Starbucks concerned the application of the fourth element: what must be shown to establish that the plaintiff is the owner of goodwill within the jurisdiction in respect of which relief is sought. The Starbucks holding treats as irrelevant any business activity outside of the jurisdiction - and, concomitantly, any reputation within the jurisdiction that is not accompanied by local customers or, at the very least, advertising expenditure. In line with Lord Neuberger's emphasis on enhancing legal certainty, insisting on customers within the jurisdiction will presumably allow courts to filter out a number of cases before reaching the more indeterminate inquiry as to consumer impressions of a foreign firm's reputation. ${ }^{39}$

\section{CONSUMER WORLDVIEWS}

For all the efficiency advantages of certainty as to the metes and bounds of property rights, it is helpful to remember that firms' interests are not the only interests at stake in the context of legal claims that protect firms' goodwill. Such claims are typically explained as providing protections for the interests of both firms and their customers. ${ }^{40}$ Certainly, prohibitions against passing off help firms to internalise their investment in quality, which would be more difficult to do if other firms

37 See for example Trade Marks Act 2002, s 17(1). In Dominion Rent A Car, above n 17, at 420, Somers J observed: "In the end the question of the existence and extent of reputation and of goodwill must be a matter of fact". See also Unicorn Products Ltd v Roban Jigg \& Tool Company (UK) Ltd [1976] FSR 169 (EWHC) at 178 , where the Court stated it is for the plaintiff to establish "that goodwill has in fact been created".

38 Erven Warninck, above n 1, at 755-756.

39 Starbucks (SC), above n 10, at [49].

40 Levi Strauss, above n 9, at 361-362. See in contrast Registrar of Trademarks $v$ Woolworths Ltd [1999] FCA 1020, (1999) 93 FCR 365 at [47], where, in a discussion by an Australian judge of the purposes of trade mark law, French J noted that, given the rise of consumer protection statutes, trade mark law might be more focused on the rights and interests of firms. See also Campomar Sociedad Limitada v Nike International Ltd [2000] HCA 12, (2000) 202 CLR 45 at [42], discussing the inherent tension between different interests of consumers and traders. 
could freely adopt the indicia of origin that symbolise a firm's goodwill. ${ }^{41}$ At the same time, consumers have an interest in not being misled. Without prohibitions on free riding, consumers would find it more difficult to find the goods or services they want. Protecting goodwill represented by indicia of origin thus facilitates competition in consumer markets. ${ }^{42}$ Firms' interests in calibrating their investment in quality thus align with consumer interests in being able to find the goods and services they want.

What does the segregation of goodwill along geopolitical lines suggest about the consumer worldview? Most obviously, the Court's holding implies that consumers' understanding and interests can, and should, also categorised along jurisdictional boundaries. The doctrine implies that the same person might be the plaintiff's customer within Hong Kong, but, within the United Kingdom, merely somebody who knows about the plaintiff's brand. Whether that knowledge might have led to a consumer thinking that there is a connection between the foreign brand and the local market entrant is legally irrelevant. The legal principle adopted in Starbucks seems to superimpose upon consumers' world views the synthetic boundaries of the nation state. ${ }^{43}$

Acknowledging the necessarily abstracted character of the consumer in passing off does not render real consumer experiences entirely irrelevant. It remains helpful to ask whether that abstraction aligns at all with the realities of consumers' apprehension of firms' branding messages. Empirical studies suggest that this is likely to be a highly contextualised inquiry, and that it is impossible to generalise about consumers' sense of place in the context of firms' branding strategies. For example, despite an increasingly globalised market for goods and services, or perhaps because of it, many marketing campaigns continue to play on the notion of nationalism. ${ }^{44}$ These campaigns

41 Qualitex Company v Jacobsen Products Company Inc 514 US 159 (1995) at 160: "The law ... discourages those who hope to sell inferior products by capitalizing on a consumer's inability to quickly evaluate the item offered for sale" (citations omitted). Note that in United States trade mark law passing off and infringement of registered rights are, for relevant purposes, largely assimilated. The United States Supreme Court has, in addition, noted that the purpose of trade marks is to "protect the public so that it may be confident that, in purchasing a product bearing a particular trade-mark which it favourably knows, it will get the product it asks for and wants to get": Two Pesos Inc v Taco Cabana Inc 505 US 763 (1992) at 782 per Stevens J.

42 William M Landes and Richard A Posner "Trademark Law: An Economic Perspective" (1987) 30 Journal of Law and Economics 265 at 285.

43 The concept of "synthetic jurisdiction" is discussed in detail by Richard Ford in "Law's Territory (A History of Jurisdiction)" (1999) 97 Mich L Rev 843. The boundaries are of synthetic jurisdictions are arbitrary visà-vis the people governed within in them. The boundaries of synthetic jurisdictions are determined and bureaucratically policed in order to achieve an independent political or legal purpose - for example, achieving a functioning democracy, in the case of electoral districts. In other contexts, these purposes might be efficient taxation or rating systems, allocation of educational resources through school zoning, and delivery of services, and other concerns of bureaucratic convenience.

44 Steven Jackson "Globalization, corporate nationalism and masculinity in Canada: Molson beer advertising and consumer citizenship" (2014) 17 Sport in Society 901. 
seek to capitalise on the idea of the nation state as a source of collective identification, and entrench notions of place. ${ }^{45}$ Other studies have shown that local populations might have an acute awareness of the particular national source of foreign-origin goods. ${ }^{46}$ And many studies suggest that consumers continue to have strong views about the connection between quality and national origin. ${ }^{47}$ The rise in the importance of geographical indications also reflects the importance of place in some consumer contexts.

At the same time, in many marketing contexts, to insist on a strictly territorial sense of place is increasingly artificial. Today, many trademarks seem to be at once from everywhere and nowhere. The components of the iPhone, for instance, come from seven different countries. ${ }^{48}$ Since the breakup of national broadcasting monopolies, consumers now have a far greater variety of weightless goods - such as audio-visual products - available to them. ${ }^{49}$ Many of these products can go globally viral in short order.

Assessing the alignment of the consumer as it is understood in the doctrine and the reality of consumer experiences might provide a useful lens for assessing the relative merits of the United Kingdom and New Zealand approaches. For instance, the New Zealand approach affords greater scope for the possibility that consumers might receive branding messages from a variety of sources, both from within the jurisdiction in which they are resident, and beyond. It also allows scope for the possibility that those branding messages might be relevant to the risk of consumer deception and that, in some contexts, consumers do not necessarily conceive of the goodwill of a business as being tethered within geopolitical borders. Of course, in the Australia/New Zealand context, it will not necessarily follow that a cross-border goodwill will be established as a matter of fact. As the Court of Appeal has noted, it is not inevitable that, in the trans-Tasman context, there will be a single goodwill. It will depend on the facts of the particular situation. ${ }^{50}$ Even so, the New Zealand case law at least allows scope for that possibility. In contrast, the Starbucks holding, with its segregation of

45 At 909 .

46 See for example Stigler and others "Westernization and tobacco use among young people in Delhi, India" (2010) 71 Social Science and Medicine 891, discussing a well-documented trend in developing nations in which goods sourced from the United States and other developed countries are considered to accord status to the purchasers.

47 Leila Hamzaoui and Dwight Merunka "The impact of country of design and country of manufacture on consumer perceptions of bi-national products' quality: an empirical model based on the concept of fit" (2006) 23 Journal of Consumer Marketing 145 at 145-146.

48 Ram Ganeshan "The iPhone 4 Supply Chain" (28 November 2010) Operations Buzz <www.operations buzz.com>.

49 Jean K Chalaby "The making of an entertainment revolution: How the TV format trade became a global industry" (2011) 26 European Journal of Communications 293 at 293-294.

50 Dominion Rent A Car, above n 17, at 401. See also Dreamtech, above n 19, at [49]. 
product goodwill along geo-political boundaries, precludes an alignment of the doctrine with consumer understanding of branding messages in almost all contexts.

The premise on which the hard line approach is based - that there is a separate Hong Kong goodwill, a separate United Kingdom goodwill, and so on - thus further diminishes the importance of consumers in the analysis. In contrast, the Dominion Rent A Car approach allows the conception of goodwill to be informed more by consumers' understanding. In some trans-Tasman contexts, for example, it might be more artificial to assume that consumers do not think in trans-Tasman terms. In applying the passing off tort, it seems excessively formalistic to assume that, in all contexts, consumers' understanding of indicia of origin exists within geopolitical silos that correspond with nations' borders. It is an approach that might, in some contexts, focus attention on how businesses actually interact with their customers, and what customers actually understand. Put simply, freeriding on another firm's local reputation, even if that firm does not have customers within the jurisdiction, might, in some instances, cause consumer confusion.

\section{PRIVATE PROPERTY AND TERRITORY}

Consideration of the relationship between territory and product goodwill also exposes deeper questions about the connection between private property, governmental power, and territorial jurisdiction. Passing off is premised on the idea that the interest protected is property in goodwill. We are now so used to the idea of territoriality of property rights that it is difficult to imagine alternative conceptions. ${ }^{51}$ On the orthodox view, the link between territorial authority and property, between imperium and dominium, implies that private property rights can only be animated within the jurisdiction by the sovereign that exercises power over the relevant territory. ${ }^{52}$ The strong conceptual connections that exist between private property and public power might also make the underlying logic of the Starbucks case appear inevitable.

This is partly why the idea advanced by Cooke P in Dominion Rent A Car that firms might own a trans-Tasman goodwill seems so radical. With its suggestion that there can be "trans-Tasman" property rights in goodwill, Dominion Rent A Car cuts right across these ideas. Cooke P's analysis points in the direction of other concepts of jurisdictional authority - concepts that do not necessarily rely on geopolitical boundaries and the connection between property and sovereignty.

51 Ford, above n 43, at 843: "We are now accustomed to territorial jurisdiction - so much that it is hard to imagine that government could be organized any other way" (emphasis in original).

52 In the trademark context, two famous United States Supreme Court cases illustrate the point: Hanover Star Milling Company v Metcalf 240 US 403 (1916); and United Drug Co v Theodore Rectanus Co 248 US 90 (1918). In broad outline, these cases held that trademark rights depend on use: rights within a particular state only arise as a business crosses state lines. A corollary of this point is that the laws of the individual states animate the property rights at issue. 
Territorial authority has, however, never been the sole way of organising thinking about jurisdiction. For example, the phenomenon of "borderland communities" that straddle different nation states is well documented. ${ }^{53}$ In earlier times, the migratory paths of animal herds were probably far more relevant to jurisdiction than borders between nation states. Recent sociological work focuses on the rise of the international city whose interests perhaps more closely align with those of the city itself as much as with the wider national polity ${ }^{54}$ And, as many cities become super diverse in their population make-up, understandings of citizenship might become increasingly complex, with allegiances pulling in different directions, to the city, the nation state, and places of origin. ${ }^{55}$ In the Aotearoa/New Zealand context, for many Māori who are resident within the Commonwealth of Australia iwi (tribal) affiliations continue to be very salient as sources of authority and identity. ${ }^{56}$

Goodwill might be an especially appropriate context in which to countenance the kind of loosening of property from the nation state - the radical premise that seems to inform the Dominion Rent A Car idea of cross-border goodwill. Goodwill, as it is understood in the context of passing off, is a kind of "psychological property". ${ }^{57}$ The strength of source identifying indicia of origin of course depends on factors that are within a firm's control - advertising expenditure and market penetration. But it also depends on consumers' appreciation of those branding messages. It is not too much of an overstatement to suggest that goodwill is "all in the mind". ${ }^{58}$

Property in unregistered marks and get-up does not depend on local trademark registers, established and run by government agencies, for its existence. Nor does this kind of property have a situs that is comparable to the situs of tangible property. Goodwill - at least in the passing off context - is a kind of property that is not obviously connected to the nation state, unless, of course, it is defined in a way that reinstates those connections, by conditioning its existence on customers within the jurisdiction. If the strength of goodwill depends on what goes on in consumers' minds, it seems to be an especially private kind of property - possibly the closest we get in the modern polity

53 Claudia Sadowski-Smith (ed) Globalization On The Line: Culture, Capital, and Citizenship at US Borders (Palgrave Macmillan, New York, 2002).

54 The path-breaking work of Professor Saskia Sassen is prominently associated with the concept of the global city. See for example Saskia Sassen The Global City: New York, London, Tokyo (Princeton University Press, Princeton, 1991).

55 Paul Spoonley and Catherine Taiapa Sport and Cultural Diversity: Responding to the Sports and Leisure Needs of Immigrants and Ethnic Minorities in Auckland: report prepared for the Auckland Regional Physical Activity and Sport Strategy (Massey University, Auckland, 2009) at 10-16.

56 Paul Hamer Māori in Australia: Ngā Māori i te Ao Moemoeā (Te Puni Kōkiri, 2007).

57 Graeme Austin "Tolerating Confusion About Confusion: Trademark Policies and Fair Use" (2008) 50 Arizona L Rev 157 at $173-174$.

58 At 167 
to pre-legal property. Accordingly, when delineating the characteristics of goodwill in the context of passing off, it might well be appropriate to think that the consumer is as, if not more, sovereign as the nation state. ${ }^{59}$ Moreover, as discussed above, the Dominion Rent A Car analysis offers the possibility of a better alignment between this understanding of goodwill and consumers' interest in not being deceived.

\section{DOCTRINAL ISSUES}

Turning to traditional doctrinal concerns, a closer look at the Starbucks case reveals a number of reasons why its logic might not be regarded as inexorable. Parts of its own doctrinal analysis are perhaps not as compelling as might first appear. For example, the Supreme Court drew support for its hard line approach from the Court of Appeal's decision in Anheuser-Busch Inc v Budejovicky Budvar NP, a well-known case that also concerned the territorial scope of goodwill. ${ }^{60}$ In AnheuserBusch, the Court of Appeal confronted the issue of the existence of Anheuser's goodwill within the United Kingdom. Anheuser-Busch was one skirmish in the ongoing battle between Anheuser-Busch, the manufacturer of the hugely successful Budweiser brand of beer (known in the United States as the "King of Beers"), and a Czechoslovakian company that exported beer in bottles bearing labels on which the words "Budweiser Budvar" were prominently displayed. ${ }^{61}$ Anheuser had engaged in only limited marketing of its beer, principally to United States personnel at military bases located in the United Kingdom and to United Kingdom residents employed at the bases. Residents of the United Kingdom might also have been exposed to the brand at United States Embassy social functions. As Oliver LJ observed in the leading judgment, no ordinary consumers could have purchased the Budweiser branded beer in the United Kingdom. Sporadic business activity was not, the Court held, a sufficient basis for a passing off action. The exposure of United Kingdom residents to the brand was merely an extension of Anheuser's United States channels of trade, and was not a sufficient basis for establishing a separate United Kingdom goodwill.

The Supreme Court characterised the ratio of Anheuser-Busch as follows: "indisputably ... in order to support a passing off claim, the claimant must establish goodwill in the form of customers for its goods or services within the jurisdiction". ${ }^{2}$ To be sure, in Anheuser-Busch, Oliver LJ took no

59 This concept of "consumer sovereignty" is discussed in detail in Don Slater Consumer Culture and Modernity (Polity Press, Cambridge, 1997); and George Stigler and Gary Becker "De Gustibus Non Est Disputandum" (1977) 67 The American Economic Review 76.

60 Anheuser-Busch Inc v Budejovicky Budvar NP [1984] FSR 413 (CA) [Anheuser] at 464.

61 The battle between these two interests has played out in a number of jurisdictions, and has even been the subject of a claim to the European Court of Human Rights, under the property clause in the 1st Protocol to the European Convention on Human Rights: Anheuser-Busch Inc v Portugal (2007) 44 EHRR 42 (ECHR).

62 Starbucks (SC), above n 10, at [26]. 
issue with the fundamental point that goodwill is territorial, describing Lord Diplock's analysis in Yap Kwee Kor as beyond dispute. ${ }^{63}$ But Oliver LJ also noted that: ${ }^{64}$

... the question, to which no very clear answer emerges from the authorities, is what form of activity on the part of the plaintiff is required before it can be said that he has a 'business' here to which goodwill can attach?

In other words, determining what is relevant to establishing goodwill as a matter of fact is a different question from whether goodwill is territorial. Anheuser-Busch might thus be read as holding simply that the plaintiff's limited penetration of the United Kingdom market was an insufficient basis on which to sustain a passing off action. This is a narrower basis than the suggestion that reputation within the jurisdiction can never be a protectable interest for the purposes of passing off. In its analysis of Anheuser-Busch, the Supreme Court thus conflates two issues. It is one thing to say that Anheuser-Busch had no customers within the jurisdiction outside of military and diplomatic circles and, for that reason, it had no protectable United Kingdom goodwill. It is quite different to say that the existence of customers within the jurisdiction is the only way that a plaintiff can establish the existence of the goodwill that it seeks to protect through the passing off action. Put simply, Anheuser-Busch does not necessarily preclude a more expansive approach to protectable goodwill - one that is at least consistent with that adopted in leading Australian and New Zealand cases.

Secondly, the hard line might transpire to be a little blurrier than the Court suggests. In the following passage, the Court discussed what having customers in the jurisdiction might mean: ${ }^{65}$

As to what amounts to a sufficient business to amount to goodwill, it seems clear that mere reputation is not enough... The claimant must show that it has a significant goodwill, in the form of customers, in the jurisdiction, but it is not necessary that the claimant actually has an establishment or office in this country. In order to establish goodwill, the claimant must have customers within the jurisdiction, as opposed to people in the jurisdiction who happen to be customers elsewhere. Thus, where the claimant's business is carried on abroad, it is not enough for a claimant to show that there are people in this jurisdiction who happen to be its customers when they are abroad. However, it could be enough if the claimant could show that there were people in this jurisdiction who, by booking with, or purchasing from, an entity in this country, obtained the right to receive the claimant's service abroad. And, in such a case, the entity need not be a part or branch of the claimant: it can be someone acting for or on behalf of the claimant.

63 Anheuser, above n 60, at 464: "The principle here enunciated by Lord Diplock is not, and indeed cannot very well be, disputed."

64 At 465 .

65 Starbucks (SC), above n 10, at [52]. 
As the passage indicates, the necessary showing of a business with customers can be achieved in a variety of ways. To take another example, in Sheraton Corp of America v Sheraton Motels Ltd Buckley J held that there was a sufficiently arguable case that a United States hotel chain had a protectable goodwill in the United Kingdom when it had London booking agents that enabled potential customers to book a room in one of the plaintiff's United States hotels. ${ }^{66}$ Indirect marketing that accompanies a service marketed through an advertising supported website might also qualify. ${ }^{67}$ And in a prominent New Zealand case, an interim injunction was granted on the basis of local publicity, advertising and contacts. ${ }^{68}$ As these cases attest, there is a range of different ways that firms expand their business across borders. The difficulty of tying down the interest protected by passing off might also provide a basis for questioning whether the hard line approach is well adapted to the modern marketplace.

Relatedly, the Supreme Court reserved its position on cases involving extensive advertising campaigns foreshadowing imminent market entry in the jurisdiction in which protection is sought. There is Singaporean authority to the effect that in such circumstances, protectable goodwill exists. ${ }^{69}$ There is also an early Chancery decision adopting the contrary position, which the Court declined to overrule. ${ }^{70}$ Lord Neuberger explained that for such activity to be characterised as goodwill within the jurisdiction it would need to be regarded as an exception to, rather than an extension of, the hard line approach. Such an exception, Lord Neuberger explained, would need to be justified by "commercial fairness rather than principle". ${ }^{71}$ The Court preferred to confront the issue when a decision on the point was required. ${ }^{72}$ In future cases, it will inevitably be asked whether commercial fairness might justify other kinds of departure from the hard line approach. ${ }^{73}$

66 Sheraton Corp of America v Sheraton Motels Ltd [1964] RPC 202 (EWHC).

67 At [67]. This point appears to acknowledge that, like the payment of the purchase price for a product, consumers' attention also has a monetary value: Barak Orbach "Indirect Free Riding on the Wheels of Commerce: Dual-Use Technologies and Copyright Liability" (2008) 57 Emory LJ 409.

68 Esanda Ltd v Esanda Finance Ltd [1984] 2 NZLR 748 (HC) at 750-751.

69 Staywell, above n 12.

70 Maxwell v Hogg (1867) LR 2 Ch App 307.

71 Starbucks (SC), above n 10, at [66].

72 The principle's blurriness is also suggested by the Court's use of the term "business". "Business" is not a term of legal art. Its meaning is shaped by context. For a business to exist, paying customers are not necessarily indispensable; nor is third party advertising. Consider an internationally-available website at which beta versions of a new video game can be played without charge. The game is promoted under a distinctive name. The game developer hopes eventually to attract players and to derive income, either through advertising or through purchased game enhancements. However, at the early stage of the roll out, the game developer firm is not sure where it might find customers and so has not invested in targeting specific jurisdictions. Delimiting the protectable interest in a passing off action to paying customers would put such sites at a significant disadvantage in the passing off context, compared with a firm that did charge 
Thirdly, there are also cases in which a departure from a strictly territorial view has been permitted, so as to prevent those free riding on others' goodwill from using indicia of origin as instruments of fraud. A prominent example is John Walker \& Sons Ltd v Henry Ost \& Co Ltd. ${ }^{74}$ In this case an injunction was granted in favour of various blenders and exporters of Scotch whisky, restraining the defendants from selling in Ecuador a mixture of Scottish single malt whisky and a local cane spirit. The second defendant added the cane spirit to the Scotch Whisky and intended that the whisky be admixed and described as Scotch Whisky, and the first defendant knew that the second defendant would do so. ${ }^{75}$ The underlying claim might be rationalised as a tort committed within the jurisdiction, ${ }^{76}$ or in terms of broader equitable duty not to allow instruments of fraud to pass into the stream of commerce. ${ }^{77}$

These kinds of doctrinal considerations suggest that the certainty promised by the hard line approach might transpire to be more illusory than real. Taken together, they would support a view that departure from the New Zealand approach is not necessarily warranted.

\section{CONCLUSION}

In 1984, Jeffries $\mathrm{J}$ observed that a strictly territorial approach to passing off "does not necessarily provide a solution for us". ${ }^{78}$ This brief article advances a few reasons why this evaluation continues to have force. A hard line territorial approach to goodwill risks entrenching an

for downloads of the games. Furthermore, other kinds of entity, such as charities, do not have customers in the traditional sense, yet the goodwill of charitable entities has been protected by the tort of passing off: see British Diabetic Association v The Diabetic Society [1996] FSR 1 (HC); and Dr Barnardo's Homes $v$ Barnardo Amalgamated Industries [1949] 66 RPC 103 (HC). In the cross-border context, the implications of the Starbucks (SC) holding for charities can be illustrated by the example of Medecins Sans Frontiers. While it is hardly appropriate to describe this entity as running a business or as having customers, it has a considerable reputation, including in jurisdictions such as New Zealand that are not specifically targeted through its websites. Many New Zealanders who are exposed to foreign media are, however, likely to know of its activities. There could be a significant risk of confusion by potential donors if another entity attempted to pass itself off as the original entity.

73 For example, Cooke P's analysis in Dominion Rent A Car is also informed by a concern with commercial fairness. For example, he opined that as a consequence of the internationalisation of trade the possibility of confusion of names tends to increase; nevertheless "it would be inequitable to refuse to allow traders to use similar names, adopted bona fide in the territories where their respective businesses began": Dominion Rent A Car, above n 17, at 406 .

74 John Walker \& Sons Ltd v Henry Ost \& Co Ltd [1970] 1 WLR 917 (EWHC) [John Walker].

75 At $923-924$.

76 At $933-934$

77 Norwich Pharmacal Co v Customs and Excise Commissioners [1974] 1 AC 133 (HL) at 145. See also British Telecommunications Plc \& Ors v One In A Million Ltd [1998] EWCA Civ 1272, [1999] 1 WLR 903.

78 Crusader Oil NL v Crusader Minerals NZ Ltd (1984) 3 IPR 171 (HC) at 181. 
artificial conception of the consumer - a conception that does not accommodate the possibility that consumers' understanding of the messages communicated by indicia of origin do not always align with geopolitical borders. While it might be awkward to conceive of property rights straddling two (or, perhaps, more) sovereign territories, the close nexus between goodwill and consumer perceptions might justify this departure from orthodoxy. And, if that idea seems too radical, a viable alternative is to recognise that consumers will, in some instances, be appropriately protected if reputation within the jurisdiction is considered a sufficient basis for invoking the passing off tort.

When the opportunity arises, it should be expected that a New Zealand court might be urged to follow the Starbucks holding. Standing against that suggestion are carefully reasoned New Zealand cases whose approaches to passing off in cross-border contexts are well adapted to some consumers' experiences in trans-Tasman markets. Even beyond the trans-Tasman context, as consumer experiences becomes more international, the softer New Zealand line might transpire to be more future-proofed than the hard line approach adopted in Starbucks. Cross-border passing off cases might be another area where reasonable minds can disagree, and New Zealand courts consider it best that we continue along our own path. 